\title{
Research on the Transformation and Upgrading Development Mode of SMEs in Jilin Province under New Normal
}

\author{
Li Huili \\ Changchun University of Finance and Economics
}

\begin{abstract}
With economic development entering "new normal", the management and operation costs of SMEs in Jilin Province are constantly increasing. The lack of funds and weak product development capabilities have seriously hinder the improvement of production efficiency and product competitiveness, and caused vicious cyclic development. Thus, the actual requirements for effectively promoting the development of SMEs in Jilin Province under new normal is to seek a new road for the transformation development of SMEs to change previous development mode. This article has elaborated not only the necessity of transformation and upgrading development modes of SMEs in Jilin Province but also a new road to promote transformation development on the basis of comprehensively analyzing the internal and external environment for SMEs in Jilin Province and the factors restricting the development of SME.
\end{abstract}

Keywords-New normal; Jilin Province; SMEs; Transformation development

\section{INTRODUCTION}

Since 2014 , the economy of our country has gradually set foot on the road of new normal, and on this road full of challenge, it is no doubt that SMEs are facing both the biggest opportunities and challenges. Jilin Province is the old industrial base in northeast of our country, and also the province that shall be noted with relatively backward economic development, and the realization of SMEs transformation development is beneficial to the promotion of diversified economic structure, and the promotion of sound and flourishing development of non-public economy, the support of increase, the promotion of creativity, the expansion of employment, and the increase of tax as well as the promotion of enterprises in comprehensively improving their own quality and core competitiveness, so as to take an invincible position in the fierce market competition.

\section{THE NECESSITY OF TRANSFORMATION AND UPGRADING DEVELOPMENT FOR SMES IN JILIN PROVINCE UNDER "NEW NORMAL"}

The SMEs in Jilin Province is an indispensable part of its economic development, but under economic "new normal", the operation cost and management cost of enterprises are constantly increased, and SMEs are facing fund deficiency, weak product development strength, seriously insufficient innovative strength, weak brand independence and other difficulties, and this has cause a huge block to the promotion of production efficiency in SMEs, and SMEs have been caught in the situation of vicious cyclic development [1]. Therefore, the inevitable requirement for effectively promoting the development of SMEs in Jilin Province under new normal is to seek a road suitable for SMEs development under new normal, and redeploy SMEs development strategy.

\section{A. The transformation of economic development mode for SMEs in Jilin Province is in need for economic development}

The realization of economic war in our province is an arduous task for our country to realize economic development; it has been put forward in "the 13th Five Year Plan" and "the 18th National Congress of the Communist Party of China", etc. the certain difficulties in transformation upgrading have existed in SMEs of our country all the time. This article briefly analyzed the various factors currently influencing the management difficulties of SMEs in Jilin Province, and at present, the transformation upgrading of SMEs in Jilin Province is free of time delay, and all bad factors that will influence the development of SMEs must be emphasized.

\section{B. Enterprise scale restructuring is in need for the transformation development of SMEs in Jilin Province}

Due to the constant progress of knowledge economy, scientific and technical revolution, the economic life of people and enterprise structure have largely changed. The social division of labor has become smaller and smaller, and the changes of product and market have also become increasingly faster; the function of knowledge, information and human resources also become increasingly important. Networking and virtualization have made the boundary of enterprise and market fuzzy. Different enterprise scales are presented, and through the merger and acquisition of SMEs, the scale can be further 
expanded, which can also increase the overall influence on the economy of Jilin Province. Enterprise scale recombination requests that SMEs enterprises in Jilin Province must fast implement transformation upgrading.

\section{The production costs and profits of enterprises are not} directly proportional, so development prospect is not good

During the period when the economic increase speed of our country slows down, the downstream pressure is increased, and under the background that the production and operation cost of SMEs is constantly increased, the economic development of Jilin Province is still worrying; the key point for the development of SMEs is to adopt effective measures, solve development difficulties, make the production and operation cost in direct proportion to the actual profits, block factors influencing the development of SMEs, constantly increase innovative strength, and promote the transformation and upgrading of SMEs. Fully apply the beneficial function of SMEs in the national economy of our country, and then promote the safe and stable operation of national economy in our country.

\section{ANALYSIS ON FACTORS RESTRICTING THE DEVELOPMENT OF SMES IN JILIN PROVINCE UNDER "NEW NORMAL"}

This part will analyze from two aspects, i.e., the external factors and internal factors:

Firstly, external factors; it plans to adopt PEST analysis method to analyze the external macro environment factors of SMEs, and carry out discussion through focusing on four dimensions, including political environment, economic environment, social environment and technological environment.

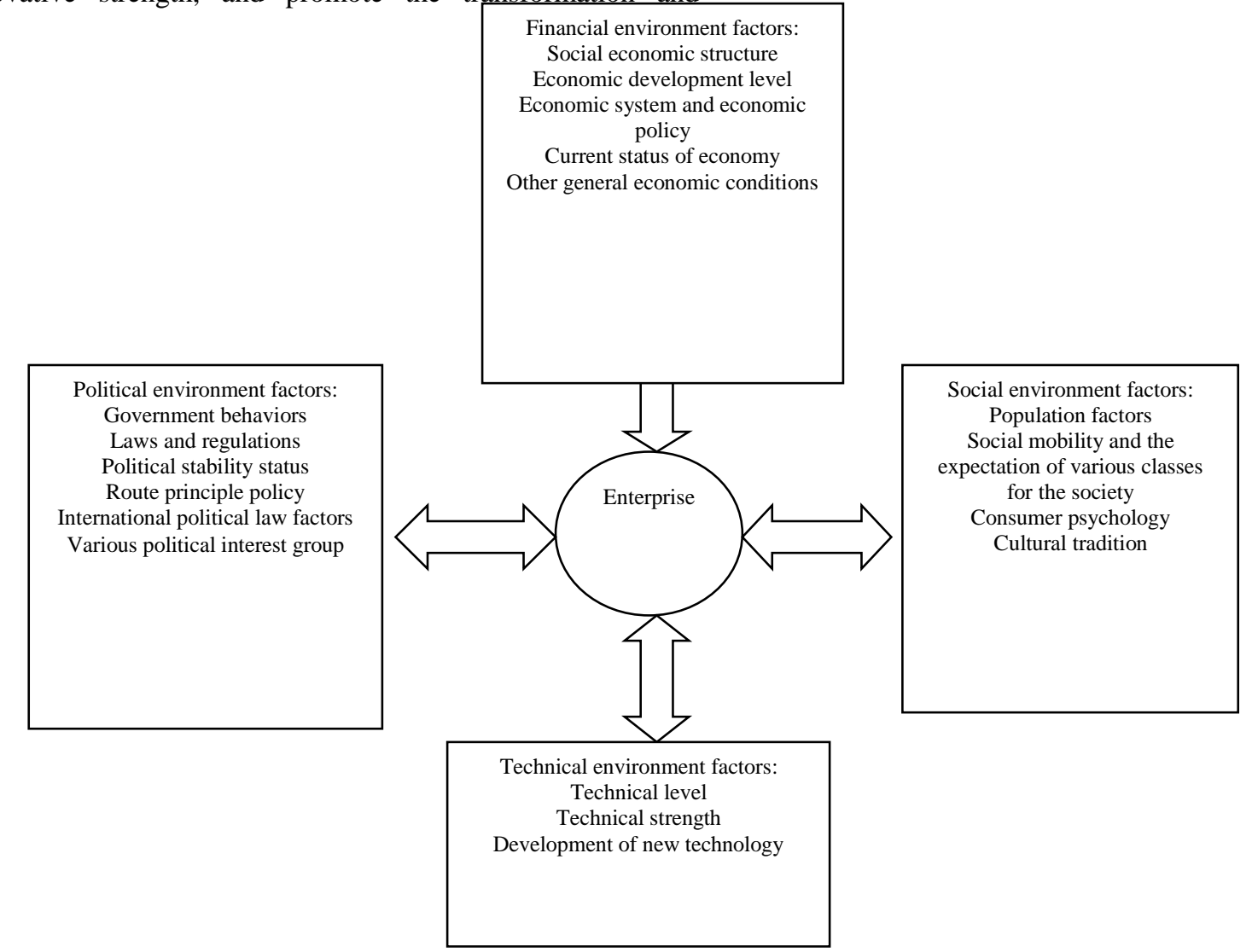

Fig. 1. Analysis on External Macro Environment with PEST Analysis Method

Secondly, internal factors; it plans to adopt questionnaire and in-depth interview method, and conduct investigation analysis on the internal factors restricting the development of SMEs through focusing on brand influence, market advantages, technical guidance and other aspects. (Refer to the following table) 
TABLE I. INTERNAL FACTOR ANALYSIS

\begin{tabular}{|c|c|c|c|c|c|c|c|}
\hline No. & $\begin{array}{l}\text { Enterprise } \\
\text { Capacity }\end{array}$ & $\begin{array}{c}\text { Is it } \\
\text { valuable }\end{array}$ & $\begin{array}{c}\text { Is it } \\
\text { deficient }\end{array}$ & $\begin{array}{l}\text { Is it hard to } \\
\text { imitate }\end{array}$ & $\begin{array}{c}\text { Is it } \\
\text { irreplaceable }\end{array}$ & $\begin{array}{l}\text { Competition } \\
\text { consequence }\end{array}$ & $\begin{array}{l}\text { Significance for } \\
\text { profits }\end{array}$ \\
\hline 1 & $\begin{array}{l}\text { Industrial } \\
\text { structure }\end{array}$ & & & & & & \\
\hline 2 & Brand influence & & & & & & \\
\hline 3 & Production scale & & & & & & \\
\hline 4 & $\begin{array}{l}\text { Technical } \\
\text { guidance }\end{array}$ & & & & & & \\
\hline 5 & $\begin{array}{c}\text { Service } \\
\text { expansion }\end{array}$ & & & & & & \\
\hline 6 & $\begin{array}{c}\text { Talent } \\
\text { advantages }\end{array}$ & & & & & & \\
\hline 7 & Fund advantages & & & & & & \\
\hline
\end{tabular}

On the basis of the aforementioned research, SWOT analysis method is utilized to summarize the contents about the internal and external conditions faced by SMEs in our province under "new normal" and other aspects, analyze and match the strengths and weakness, opportunities and threats faced by SMEs in Jilin Province, select scientific and reasonable development strategy, seek opportunities through reform and fully play the internal strength and utilize external development.

TABLE II. ANALYSIS ON THE INTERNAL AND EXTERNAL CONDITIONS WITH SWOT ANALYSIS METHOD

\begin{tabular}{|l|c|c|}
\hline \multicolumn{1}{|c|}{ Internal factors External factors } & $\begin{array}{c}\text { Strength-S } \\
\text { List out the strength }\end{array}$ & $\begin{array}{c}\text { Weakness-W } \\
\text { List out the weakness }\end{array}$ \\
\hline $\begin{array}{l}\text { Opportunities-O } \\
\text { List out the opportunities }\end{array}$ & $\begin{array}{c}\text { Growth-type strategy (SO strategy) } \\
\text { Find out opportunities, and give full } \\
\text { play to strengths }\end{array}$ & $\begin{array}{c}\text { Torsional strategy (WO strategy) } \\
\text { Improve weakness and utilize } \\
\text { opportunities }\end{array}$ \\
\hline $\begin{array}{l}\text { Threats-T } \\
\text { List out the threats }\end{array}$ & $\begin{array}{c}\text { Various operation strategies (ST } \\
\text { strategy) } \\
\text { Avoid threats and utilize advantages }\end{array}$ & $\begin{array}{c}\text { Defense-type strategy (WT strategy) } \\
\text { Eliminate weakness and avoid threats }\end{array}$ \\
\hline
\end{tabular}

Through the aforementioned analysis, the transformation of SMEs in Jilin Province can be specifically summarized as macro environment and micro actual transformation, and generally speaking, it mainly includes the financial environment, legal system, administrative system, industrial structure and the transformation of the enterprise and employees themselves [3]. The importance degree of SMEs in the national economy of our country has been increasingly highlighted during the current period, and in the development progress of SMEs in Jilin Province, some key problems hindering the transformation upgrading have increasingly emerged, and the specific performance is as follows:

\section{A. Bad financial environment and financing channel}

Since the occurrence of financial crisis, the original developed economy has been encountered with serious contusion, the economy has been decreased, and the consumption capacity has also presented an obvious decrease trend, but European Debt Crisis is becoming increasingly fierce, and the global economic prospect is uncertain.[3]Especially for Jilin, as one of the undeveloped provinces, the main problems are as follows: firstly, SMEs commonly have the situation of difficult financing, and it is extremely difficult to obtain funds from state-owned department; secondly, SMEs cannot establish financial enterprises, so this will cause the failure for SMEs in obtaining the requested fund through private financing, and the financial resource configuration has also presented a distorted phenomenon. Currently, the credit guaranty enterprises of Jilin Province develop fast, but most of them are small-scaled, without higher guarantee capacity, and under the condition of fast increase of enterprise financing demand, it is still impossible to meet the financing demand of SMEs, and has 
caused the regional liquidity shortage phenomenon in the financing of SMEs

\section{B. Unreasonable industrial structure and relatively low overall level}

Due to the restriction of economic development in Northeast China Region and the influence of traditional concept, the overall development level of SMEs in Jilin Province is relatively low. Firstly, when being compared with economic developed region, the quantity of SMEs in Jilin Province is obviously decreased. Up till the end of 2014, the quantity of SMEs in Jilin Province is 80,000 according to the statistics, and it can merely occupy $24.60 \%$ of that in Beijing City, and $11.8 \%$ of Jiangsu Province; when being compared with developed regions, the gross output of SMEs in Jilin Province is obviously backward. Currently, the most key obstructive factor for the economic development of Jilin Province in our country is industrial structure, and uncoordinated regional development is also one important reason. As can be seen from the current conditions about the industrial structure of SMEs in Jilin Province, there are still many SMEs having the same problems with traditional enterprises, with strong product simplicity, low additional performance and backward technical level, so in the market competition process, these enterprises are always under backward status[2]. Besides, since most SMEs in Jilin Province are family enterprises, and partnership enterprises, with single equity structure, closed status, and low socialization degree, this has restricted the further development of enterprises. The irregular enterprise management and financial management are insufficient to form worries about realizing the development prospect of getting bigger and stronger.

\section{Unsound legal system and the restrictions of administrative management system}

Firstly, the local government doesn't pay high attention to SMEs. Due to the influence of deep-rooted bureaucracy thought in China, the performance evaluation standard mainly focuses on the increase of GDP, and basically, the local government merely pays attention to the domestic GDP, and doesn't care about the interests of SMEs. In order to construct more large-scaled enterprises, the local basically adopts the decrease of admittance threshold; secondly, administrative monopoly has restricted the development of SMEs in Jilin Province. Due to various inequality factors of SMEs in Jilin Province, the difficulties encountered thereby cannot arouse attention. The development space for SMEs in Jilin Province is small, and the development potential cannot be comprehensively excavated, so it is extremely difficult to realize successful transformation under such environment.

\section{Small enterprise production scale, the lack of innovative awareness and low quality of enterprise employees}

Currently, the overall quality of staff in Jilin Province of our country is not high, and according to incomplete statistics, currently, among the 40,000 staff in Jilin Province, staff with junior high school and above education background can occupy $60 \%$, which means that above a half of them are illiteracies, and it seriously lacks in senior technicians, and merely less than $2 \%$ are senior workers. In the intelligent development society, there is no doubt that such phenomenon cannot meet social requirements. However, as the undeveloped province, this problem is more prominent in Jilin Province, so this shall not only arouse the attention of the society and the state, but also the high attention of enterprises internally and the employees thereof; besides, it is worthy of our careful reflection and treatments; the connotation of staff quality in enterprises refers to elaboration about the knowledge skills, value concept and self-cognition of employees engaged in different kinds of work inside the organization and other contents.

Since the SMEs in Jilin Province lack in technical innovation capacity as a whole, and don't have the core technology of proprietary intellectual property rights, this has caused no initiative in product positioning, and no speaking right in brand construction, and seriously weakens the core competitiveness of enterprises [4]. Enterprise employees are content with the status quo, and cannot form written employee working system, with the negative and slack situation of individual employees, and rough-and-ready handling style, and the failure in implementing well the special education of "three-strictness and three-implementation". It lacks in correct ideology and morality guidance and powerful specification, and has no good employee motivation mechanism; besides, the potential of employees are not fully played.

\section{EFFECTIVE MEASURES FOR THE SUCCESSFUL TRANSFORMATION UPGRADING OF SMES IN JILIN PROVINCE UNDER "NEW NORMAL"}

On the basis of the analysis on the internal and external factors restricting the transformation upgrading development of SMEs in Jilin Province, we should construct effective mode adapted to the transformation upgrading of SMEs in Jilin Province under "new normal", and scientifically implement and utilize it.

\section{A. Construct transformation and upgrading development mode of SMEs in Jilin province under "new normal".}

1) The transformation upgrading mode based on the value chain of enterprises.

It refers to adopting the value chain on the basis of the characteristics of the enterprise itself to complete transformation upgrading. Specifically, it includes ecological development type, creativity implantation type and progressive ascending type. 
2) Realize network transformation upgrading mode based on industry.

In combination with the external environment factors, realize the successful transformation of enterprises through integrating industrial division network, and the scale brought by cluster as well as the spillover effect. It specifically includes regional brand linkage, functional welfare, industrial division forcing and industrial chain extension and other types.

\section{B. Effectively apply the transformation and upgrading} development mode of SMEs in Jilin Province under "new normal"

\section{1) Select suitable transformation mode.}

The choice made by enterprises considering which kind of dimension is adopted as the transformation upgrading mode is under the joint effect of various internal and external factors of the enterprise, and the enterprise transformation mode[6] will be influenced by various factors, and the actual conditions are as follows: (1) In case that the enterprise is built on the basis of value chain transformation mode, it is requested to regard enterprise brand, marketing, service and the capacities of other aspects as the key points for transformation, and then in combination with its own advantages, select suitable innovative factors, conduct effective integration of innovative factors in all fields, so as to promote the transformation upgrading of all factors of the enterprise. (2) When enterprises adopt the transformation upgrading mode based on industrial network, it is requested to actively utilize the good system environment built by the local government, and realize its own transformation upgrading.

2) Cultivate enterprise transformation capacity.

(1) The capacity for recognizing internal and external opportunities and challenge; under "new normal", it is requested to cultivate the capacity of SMEs to correctly and timely recognize internal and external opportunities and challenge.[5]

(2) Formulate clear and reasonable transformation strategy capacity. Strategy selection shall comprehensively combine the current resource conditions of enterprises, the development vision and business development conditions, and even consider the matching systems of the enterprise, construct systematic reform system, so as to confirm the valid implementation of strategies.

(3) The innovative capacity in the organization; an organization with innovative capacity must ensure the positive motivation guarantee for innovative behaviors in system, procedures and other aspects. The main approach can be: encouraging employees to constantly study new knowledge and improve the working skill of individuals; the opinions put forward by employees may be accepted; enterprise culture encouragement mode can break traditional limitation from system and procedures, and seek a brand new working mode.

(4) The reform of management capacity; the organization must constantly increase new convention, and in the transformation process, it is requested to constantly make assumption, and dare to change on the basis of original stable status.

(5) The adaptation of leadership in the transformation process; in the transformation process, enterprises will change their previous calm phenomenon, and the leading personnel must change from their previous mind, actively face the reality of fast change. The adaptation of leadership is mainly reflected in the handing capacity for facing contradictory issues.

(6) Available resources and the capacity for effectively using resources; encourage organization individuals to change thought limitation, think about problems from various aspects, and realize comprehensive and sustainable development of innovative spirits and internal enterprising spirit.

\section{CONCLUSION}

To sum up, under economic "new normal", the transformation development process of SMEs in Jilin Province has encountered with various external obstacles and restraining factors; this article uses PEST analysis and SWOT analysis method to find the corresponding influencing factors, and then put forward corresponding solutions: constructing the transformation upgrading development mode for SMEs in our province under "new normal"; effectively apply the transformation upgrading development mode for SMEs in Jilin Province under "new normal".

\section{ACKNOWLEDGMENT}

Fund Project 1: "13th Five Year Plan" Social Science Research Plan Project for the Education Department of Jilin Province, Project Name: Research on the Transformation Upgrading Development Mode of SMEs in Jilin Province under New Normal, Project No.: JJKWH Zi [2016] No. 553

Fund Project 2: "13th Five Year Plan" Social Science Research Plan Project for the Education Department of Jilin Province, Project Name: Research on the Development Strategy of Private Express Delivery Industry Based on Clients' Satisfaction Degree, Project No.: JJKWH Zi [2016] No. 552

About the Author: Li Huili (1982.2.9-), Gender: female; Native Place: Changchun; Title: Lecturer; Degree: Master; Research Direction: Human Resource Management. 


\section{REFERENCES}

[1] Wang Mingpeng. Systematic Research on the Influencing Factors of SMEs in Our Country [D]. Beijing University of Posts and Telecommunications, 2015.

[2] Sun Weiguang. Research on the Transformation of Chinese Exportoriented SMEs under the Background of New Normal [D]. Yunnan University, 2015.

[3] Yin Yutao. Analysis on the Development Strategy of SMEs under Circulated Economy [J]. Special Zone Economy, 2010, (06): 214-215.

[4] Zhang Zhanbin and Zhou Yuehui Reflection on Several Issues of Chinese Economic New Normal [J]. Reform of the Economic System, 2015 (1).

[5] Zhang Li, Primary Investigation about the Current Development Status of Small and Micro Businesses in Our Country [J]. Technology Forum, 2015 (24).

[6] Xing Zuli and Liu Chuanchu. Rent-seeking and the Macro Characteristics of Chinese Transformation Economy [J]. Macroeconomic Study, 2010 (3). 